\title{
The hygiene hypothesis: current perspectives and future therapies
}

This article was published in the following Dove Press journal:

ImmunoTargets and Therapy

27 July 2015

Number of times this article has been viewed

\author{
Leah T Stiemsma ${ }^{1,2}$ \\ Lisa A Reynolds ${ }^{3}$ \\ Stuart E Turvey 1,2,4 \\ B Brett Finlay ${ }^{1,3,5}$
}

'Department of Microbiology \& Immunology, University of British Columbia, ${ }^{2}$ The Child and Family Research Institute, ${ }^{3}$ Michael Smith Laboratories, University of British Columbia, ${ }^{4}$ Department of Pediatrics, University of British Columbia, ${ }^{5}$ Department of Biochemistry and Molecular Biology, University of British Columbia, Vancouver, BC, Canada
Correspondence: B Brett Finlay Michael Smith Laboratories, 2329 West Mall, University of British Columbia, Vancouver, BC, V6T IZ4, Canada Email bfinlay@msl.ubc.ca
Abstract: Developed countries have experienced a steady increase in atopic disease and disorders of immune dysregulation since the 1980s. This increase parallels a decrease in infectious diseases within the same time period, while developing countries seem to exhibit the opposite effect, with less immune dysregulation and a higher prevalence of infectious disease. The "hygiene hypothesis", proposed by Strachan in 1989, aimed to explain this peculiar generational rise in immune dysregulation. However, research over the past 10 years provides evidence connecting the commensal and symbiotic microbes (intestinal microbiota) and parasitic helminths with immune development, expanding the hygiene hypothesis into the "microflora" and "old friends" hypotheses, respectively. There is evidence that parasitic helminths and commensal microbial organisms co-evolved with the human immune system and that these organisms are vital in promoting normal immune development. Current research supports the potential for manipulation of the bacterial intestinal microbiota to treat and even prevent immune dysregulation in the form of atopic disease and other immune-mediated disorders (namely inflammatory bowel disease and type 1 diabetes). Both human and animal model research are crucial in understanding the mechanistic links between these intestinal microbes and helminth parasites, and the human immune system. Pro-, pre-, and synbiotic, as well as treatment with live helminth and excretory/secretory helminth product therapies, are all potential therapeutic options for the treatment and prevention of these diseases. In the future, therapeutics aimed at decreasing the prevalence of inflammatory bowel disease, type 1 diabetes, and atopic disorders will likely involve personalized microbiota and/or helminth treatments used early in life.

Keywords: inflammatory bowel disease, microbiota, helminths, atopic disease, type 1 diabetes

\section{Introduction}

The Millennial generation (born 1980-1999) displays a marked increase in prevalence of atopic diseases (asthma, anaphylaxis, allergic rhinitis, food allergy, and atopic dermatitis [AD]) and immune-mediated disorders (including type 1 diabetes [T1D], and inflammatory bowel disease [IBD]), which have been steadily increasing in developed countries since the 1980s. ${ }^{1-3}$ These disorders comprise a unique sector within immune dysregulation characterized by an irrational immune cell response to a foreign (or in the case of autoimmunity, a self) antigen which would, under normal circumstances, not occur. The short developmental timeframe of these diseases (from the 1980s onward, roughly within one generation) decreases the likelihood that a changing genetic component is significantly involved. Hence, researchers are assessing the potential effects of environmental factors, such as diet and antibiotic exposure. ${ }^{4}$ Furthermore, the increase in immune disorders and 
atopic diseases parallels a decrease in prevalence of infectious diseases over the same time period, which can be attributed to increased vaccine and antibiotic treatments, and improved sanitation standards. ${ }^{4}$ An in-depth look at the effects of these "hygienic" environmental factors suggests that lack of exposure to infectious agents may be the culprit for the increase in immune-mediated and atopic disease prevalence, a concept most commonly referred to today as the "hygiene hypothesis". This review aims to provide readers with the historical and current perspectives of the hygiene hypothesis and to elaborate on the modern scientific and medical applications of this theory. We also discuss the increasing evidence connecting the hygiene hypothesis to the development of atopic disease and immune-mediated disorders, in addition to discussing future therapies capitalizing on this knowledge.

\section{A history of "hygiene" in immune modulation}

One of the first observations relating infectious agents and immune dysregulation occurred in Western Nigeria, where Greenwood noted the low incidence of rheumatoid arthritis and deduced that this low incidence may be attributed to immunological disturbance resulting from frequent exposure to malaria (Figure 1). ${ }^{5}$ Greenwood et al also observed suppressed spontaneous autoimmune disease, characterized by delayed Coombs test positivity and reticulocytosis in mice infected with Plasmodium berghei (a causative agent of rodent malaria). ${ }^{6}$ In the late 1970 s, a discrepancy between urbanized and rural environments emerged when Gerrard et al observed a lower prevalence of allergy in indigenous populations in Northern Canada compared to urban Caucasian populations. ${ }^{7}$

In 1989, Strachan proposed the hygiene hypothesis of allergic disease after observing that hay fever was less common among children with older siblings. ${ }^{8}$ He reasoned that children growing up in larger families may experience increased exposure to microbes in early childhood due to inevitable unhygienic contact with older siblings or prenatal exposure from the mother infected by similar unhygienic contact. ${ }^{8}$ Strachan proposed that this increased microbial exposure in early life could protect children from developing immune hypersensitivities later in life. ${ }^{8}$ Strachan et al supported this theory by assessing family history, medical records, and allergy skin prick test results in a cohort of 11,765 children and found that household size was inversely correlated with the development of hay fever. ${ }^{9}$ Additional epidemiological studies supporting the hygiene hypothesis associate a reduction in allergen sensitization with pet exposure, daycare attendance, and an increased number of siblings. ${ }^{10,11}$ Early childhood infections have also been associated with decreased atopy in children. A retrospective case-control study showed that atopic patients exhibited a lower prevalence of Toxoplasma gondii, Helicobacter pylori, and hepatitis A when compared to nonatopic controls. ${ }^{12}$ More recently, single-strand polymorphism analysis and culture techniques were used to identify microbial exposures among two cohort studies of European children. ${ }^{13}$



Figure I Timeline displaying key findings leading up to the proposal of the "hygiene hypothesis", proposal of the "old friends" and "microflora" hypotheses, and key microbiological and immunological findings in support of these theories.

Abbreviation: Th, T-helper. 
In both cohort studies, researchers found that children growing up on farms in Central Europe encountered a wider range of microbial exposures and had a lower prevalence of asthma and atopy than the reference group. ${ }^{13} \mathrm{~A}$ closer look at the immunological mechanisms behind Strachan's hygiene hypothesis of allergic disease will enhance the connection between early life infectious exposures and the development of immune tolerance.

\section{Immunological support for the hygiene hypothesis}

In 1986, just prior to Strachan's proposal of the hygiene hypothesis, Mosmann et al described the T-helper (Th)1 and Th2 cell subtypes, providing an immunological basis for this otherwise observational theory. ${ }^{14}$ They discovered that fully differentiated murine $\mathrm{CD}^{+} \mathrm{T}$-cells secreted two separate cytokine profiles (Th1: IFN- $\gamma$; Th2: IL-4) and that the different cytokines produced two different inflammatory responses. ${ }^{14}$ Th2 cells play a primary role in the allergen sensitization process. ${ }^{15}$ Infection with viruses and intracellular bacteria generally stimulates Th1 immune responses, which suppress Th2 cytokine activity through the induction of IFN- $\gamma \cdot{ }^{16,17}$ Consequently, the concept of a Th1 versus Th2 balance arose whereby a Th1-dominated immune phenotype (brought on by early life microbial exposures) was thought to inhibit atopic immunopathology. Research related to helminth parasites stimulated the need for further explanation beyond this binary view, as these organisms paradoxically induce Th2 responses while suppressing allergic reactivity. ${ }^{18} \mathrm{~T}$-cell plasticity and additional T-cell phenotypes (eg, Th17, Th9, and T regulatory [Treg] cells) have more recently been implicated in the control of hypersensitivity disorders. ${ }^{19,20}$ Additionally, many innate cytokines (eg, IL-25, IL-33, and thymic stromal lymphopoietin) and cell types (eg, eosinophils, basophils, mast cells, and epithelial cells) also play significant roles in hypersensitivity disease..$^{21}$ It is now understood that the process of allergen presentation and consequent initiation of the allergic response involves both the innate and adaptive branches of the immune system. Thus, the immunological foundation of the hygiene hypothesis has been modified to consider the balance between many adaptive and innate immune cell populations. Further, extending the hygiene hypothesis to account for the role of various parasites (ie, intestinal helminths) and microbiota compositional shifts provides insight into how early life environmental exposures shape the human immune system. These extensions are known as the "old friends" and "microflora" hypotheses, respectively. ${ }^{22,23}$

\section{The old friends hypothesis: parasitic helminths}

The old friends hypothesis, proposed by Rook et al, notes the co-evolution of microorganisms and macroorganisms, such as parasitic helminths, with the development of the human immune system. ${ }^{22}$ Similar to the hygiene hypothesis, it suggests that these organisms are required for normal immune system development. ${ }^{22,24}$ For example, a study in Gabon found that school children diagnosed with schistosomiasis, caused by infection with helminth parasites from the Schistosoma genus, exhibited lower levels of allergen reactivity than their uninfected classmates. ${ }^{25}$ Since then, additional studies have highlighted this seemingly protective effect of helminths in many mouse models of allergic diseases. ${ }^{26-28}$ A live Heligmosomoides polygyrus (H. polygyrus; a murine helminth parasite) infection reduces lung cellular influx, eosinophilia, allergen recall responses, bronchial hyperreactivity, and histopathology in ovalbumin (OVA)- and house dust mite (HDM)-driven mouse models of asthma. ${ }^{26,27}$ Additionally, Schistosoma mansoni infection has been shown to be protective in an experimental mouse model of fatal anaphylaxis, probably due to the induction of a regulatory IL-10-producing $\mathrm{B}$ cell population. ${ }^{28}$ There is also experimental animal model evidence suggesting the ability of helminths to ameliorate symptoms of T1D and colitis (Table 1). Non-obese diabetic (NOD) mice spontaneously develop T1D, which is significantly inhibited when they are infected with $H$. polygyrus or the filarial nematode Litomosoides sigmodontis. ${ }^{29-32} \mathrm{Helm}-$ inth infection has also been shown to reduce inflammation in murine models of colitis. ${ }^{33}$ Studies such as these support live helminth infection as a potential therapy to combat hypersensitivity and other immune disorders; however, referring back to Strachan's original hygiene hypothesis, the question of whether live helminth infection in early life is an effective treatment to protect against the development of these disorders is still unclear. Future therapeutics to treat immune dysregulation may involve the excretory/secretory (ES) products of these parasites and/or the intestinal microbiota (Tables 1 and 2).

\section{The microflora hypothesis}

The microflora hypothesis is another modern extension of the hygiene hypothesis, which suggests that early life perturbations (driven by factors such as antibiotic use, infection, or diet) to the bacteria residing in the human intestine (the intestinal microbiota) disrupt the normal microbiota-mediated mechanisms promoting immunological tolerance and consequently bias the immune system toward 
Table I Helminth-based therapeutic studies

\begin{tabular}{|c|c|c|c|c|}
\hline Organism & Disease & Treatment & Description of effects & Reference \\
\hline Mouse & $\begin{array}{l}\text { OVA-alum and Der pl-alum } \\
\text { (HDM allergen)-driven models } \\
\text { of allergic airway inflammation }\end{array}$ & H. polygyrus larvae & $\begin{array}{l}\text { H. polygyrus-infected mice had reduced airway cellular } \\
\text { infiltrates (including reduced } \\
\text { eosinophilia and neutrophilia), reduced lung type } 2 \\
\text { cytokines, and reduced lung histopathology }\end{array}$ & 26 \\
\hline Mouse & $\begin{array}{l}\text { OVA-alum-driven model of } \\
\text { allergic airway inflammation }\end{array}$ & H. polygyrus larvae & $\begin{array}{l}\text { H. polygyrus-infected mice had reduced airway } \\
\text { eosinophilia, reduced bronchial hyperreactivity, } \\
\text { and reduced allergen-specific Th2 responses }\end{array}$ & 27 \\
\hline Mouse & $\begin{array}{l}\text { OVA-alum-driven model of } \\
\text { allergic airway inflammation }\end{array}$ & HES & $\begin{array}{l}\text { HES given at allergen sensitization or challenge reduced } \\
\text { airway cellular infiltrates and lung eosinophilia }\end{array}$ & 110 \\
\hline Mouse & $\begin{array}{l}\text { Alternaria alternata-driven model } \\
\text { of allergic airway inflammation }\end{array}$ & HES & $\begin{array}{l}\text { HES blocked lung eosinophilia, IL-33 release, and innate } \\
\text { lymphoid cell type } 2 \text { cytokine production }\end{array}$ & 111 \\
\hline Mouse & TNBS-induced colitis & $\begin{array}{l}\text { Schistosoma mansoni- or } \\
\text { Ancylostoma caninum-soluble } \\
\text { proteins }\end{array}$ & $\begin{array}{l}\text { Intraperitoneal helminth protein administration } \\
\text { reduced macroscopic inflammation scores and reduced } \\
\text { proinflammatory cytokine release (IL-I7 and IFN- } \gamma \text { ) }\end{array}$ & 112 \\
\hline Mouse & Systemic-fatal anaphylaxis & S. mansoni cercariae & S. mansoni-infected mice were protected from anaphylaxis & 28 \\
\hline Mouse & $\begin{array}{l}\text { TID (spontaneous } \\
\text { development in NOD mice) }\end{array}$ & H. polygyrus larvae & H. polygyrus infection delayed disease onset & 29,30 \\
\hline Mouse & $\begin{array}{l}\text { TID (spontaneous } \\
\text { development in NOD mice) }\end{array}$ & $\begin{array}{l}\text { Litomosoides sigmodontis } \\
\text { larvae }\end{array}$ & L. sigmodontis infection prevented disease onset & 31,32 \\
\hline Mouse & $\begin{array}{l}\text { OVA-alum-driven model of } \\
\text { allergic airway inflammation and } \\
\text { DSS-induced colitis }\end{array}$ & $\begin{array}{l}\text { Recombinant cysteine } \\
\text { protease inhibitor (cystatin) } \\
\text { of Acanthocheilonema viteae }\end{array}$ & $\begin{array}{l}\text { A. viteae cystatin treatment during OVA sensitization or } \\
\text { prior to OVA challenge reduced airway BALF cell counts, } \\
\text { airway eosinophilia, bronchial hyperreactivity, and lung } \\
\text { histopathology. In the DSS-colitis model, intrarectal } \\
\text { A. viteae cystatin resulted in significant reductions in } \\
\text { colonic inflammatory index compared to control animals }\end{array}$ & 114 \\
\hline Mouse & DSS-induced colitis & $\begin{array}{l}\text { Ancylostoma ceylanicum crude } \\
\text { extract or ES products }\end{array}$ & $\begin{array}{l}\text { Helminth-product-treated mice had reduced clinical and } \\
\text { colonic microscopic inflammation scores compared to } \\
\text { control mice }\end{array}$ & 113 \\
\hline Mouse & $\begin{array}{l}\text { TID (spontaneous } \\
\text { development in NOD mice) }\end{array}$ & $\begin{array}{l}\text { S. mansoni infection, or } \\
\text { treatment with soluble } \\
\text { worm or egg extracts }\end{array}$ & $\begin{array}{l}\text { Exposure to worm or egg extract prevented disease } \\
\text { onset if given before } 4 \text { weeks of age }\end{array}$ & 116 \\
\hline Mouse & DSS-induced colitis & ES products from $A$. caninum & $\begin{array}{l}\text { Exposure to helminth products reduced intestinal } \\
\text { proinflammatory cytokine expression }\end{array}$ & 115 \\
\hline Humans & $C D$ and $U C$ & Live Trichuris suis eggs & $\begin{array}{l}\text { Three out of four CD patients entered remission; fourth } \\
\text { patient had a reduction in symptoms. UC patients had a } \\
\text { reduction in clinical colitis activity index }\end{array}$ & 106 \\
\hline Humans & $C D$ & Live $T$. suis ova & $\begin{array}{l}79.3 \% \text { of patients had a reduction in CD activity index or } \\
\text { remitted }\end{array}$ & 103 \\
\hline Humans & $C D$ & Live $T$. suis ova & $\begin{array}{l}\text { All doses tested were well tolerated and did not result in } \\
\text { treatment-related side effects. Efficacy of a reduction in } \\
\text { disease severity not assessed }\end{array}$ & 104 \\
\hline Humans & UC & Live $T$. suis ova & $\begin{array}{l}\text { A reduction in disease activity was seen in helminth- } \\
\text { infected patients compared to placebo group, although } \\
\text { this did not reach statistical significance }\end{array}$ & 108 \\
\hline Humans & $C D$ & Necator americanus larvae & $\begin{array}{l}\text { IBD questionnaire results were improved, and cumulative } \\
C D \text { activity index scores were decreased }\end{array}$ & 105 \\
\hline Humans & Allergic rhinoconjunctivitis & N. americanus larvae & $\begin{array}{l}\text { Infection well tolerated; no significant differences in } \\
\text { allergic symptoms between groups given placebo or } \\
\text { N. americanus larvae }\end{array}$ & 107 \\
\hline
\end{tabular}

Abbreviations: OVA, ovalbumin; alum, potassium aluminum sulfate; ES, excretory/secretory; HES, H. polygyrus excretory/secretory product; HDM, house dust mite; BALF, bronchoalveolar lavage fluid; IL, interleukin; IFN, interferon; DSS, dextran sulfate sodium; TNBS, 2,4,6-trinitrobenzene sulfonic acid; TID, type I diabetes; NOD, non-obese diabetic; CD, Crohn's disease; UC, ulcerative colitis; IBD, inflammatory bowel disease; Th, T-helper.

a state that promotes hypersensitivity disorders. ${ }^{23}$ Current research focuses on the mechanisms by which the intestinal microbiota influences immune system development and homeostasis, and potentially confers protection against immune dysregulation. ${ }^{35-50}$

\section{A mutualistic bond}

The human intestine is a densely populated zone in the body harboring a diverse microbial community of 500-1,000 different bacterial species among other microbes such as archaea, eukarya, and viruses. ${ }^{34}$ The most striking illustration 
Table 2 Microbiota-based therapeutic studies

\begin{tabular}{|c|c|c|c|c|}
\hline Organism & Disease & Treatment & Description of effects & Reference \\
\hline Rat & $\begin{array}{l}\text { HLA-B27 transgenic rats } \\
\text { (colitis model) }\end{array}$ & Inulin and FOS & $\begin{array}{l}\text { Decreased severity of intestinal inflammation (FOS treatment } \\
\text { resulted in less disease severity than inulin) }\end{array}$ & 135 \\
\hline Rat & TID (BB-DP rat model) & Lactobacillus johnsonii & $\begin{array}{l}\text { Administration of } L \text {. johnsonii isolated from BB-diabetes- } \\
\text { resistant rats resulted in decreased incidence of TID and } \\
\text { reduced levels of IFN } \gamma \text { and inducible nitric oxide synthase in } \\
\text { BB-diabetes-prone rats }\end{array}$ & 92 \\
\hline Mouse & $\begin{array}{l}\text { TID (spontaneous } \\
\text { development in NOD mice) }\end{array}$ & $\begin{array}{l}\text { VSL\#3 (probiotic compound: } \\
\text { containing Bifidobacteria, } \\
\text { Lactobacilli, and Streptococci } \\
\text { species). }\end{array}$ & Reduced insulitis and decreased beta cell destruction & 124 \\
\hline Mouse & $\begin{array}{l}\text { HDM-driven model of } \\
\text { allergic airway inflammation }\end{array}$ & $\begin{array}{l}\text { Diet supplemented with } 30 \% \\
\text { pectin }\end{array}$ & $\begin{array}{l}\text { Increased concentrations of SCFAs and decreased allergic } \\
\text { inflammation in the lungs of murine HDM model of airway } \\
\text { inflammation }\end{array}$ & 46 \\
\hline Mouse & $\begin{array}{l}\text { OVA-alum-driven model of } \\
\text { airway inflammation }\end{array}$ & $\begin{array}{l}\text { scGOS/lcFOS, and scGOS/ } \\
\mathrm{lcFOS}+\mathrm{pAOS}\end{array}$ & Suppressed airway inflammation and hyperresponsiveness & 134 \\
\hline Mouse & CMA model & $\begin{array}{l}\text { scGOS/lcFOS + Bifidobacterium } \\
\text { breve }\end{array}$ & $\begin{array}{l}\text { Increased serum galectin- } 9 \text { and galectin- } 9 \text { expression by } \\
\text { intestinal epithelial cells. Also, reduced acute allergic skin } \\
\text { reaction and mast cell degranulation }\end{array}$ & 137 \\
\hline Rat & TID (STZ model) & $\begin{array}{l}\text { Lactobacillus gasseri engineered } \\
\text { to secrete GLP-I (I-37) }\end{array}$ & $\begin{array}{l}\text { GLP-I }(I-37) \text { secreted by } L \text {. gasseri stimulated rat intestinal } \\
\text { epithelial cells to become glucose-responsive insulin-secreting } \\
\text { cells. Resulted in increased insulin levels and glucose tolerance } \\
\text { in diabetic rats }\end{array}$ & 125 \\
\hline Mouse & $\begin{array}{l}\text { IBD (IL-I0-deficient colitis } \\
\text { model) }\end{array}$ & Lactobacillus plantarum & $\begin{array}{l}\text { Prior to SPF flora exposure, treatment of GF IL- } 10 \text { deficient } \\
\text { mice with } L \text {. plantarum and continued } L \text {. plantarum therapy } \\
\text { attenuated colitis }\end{array}$ & 122 \\
\hline Mouse & $\begin{array}{l}\text { IBD (DSS-induced colitis } \\
\text { model) }\end{array}$ & $\begin{array}{l}\text { Lactobacillus rhamnosus, } \\
\text { L. plantarum, Lactobacillus casei, } \\
\text { Lactobacillus lactis, Bifidobacterium } \\
\text { lactis, Bifidobacterium bifidum, } \\
\text { Bifidobacterium adolescentis, } \\
\text { Bifidobacterium infantis }\end{array}$ & $\begin{array}{l}\text { Mice receiving the probiotic mixture for } 7 \text { days prior to DSS } \\
\text { induction of colitis showed reduced mucosal inflammation } \\
\text { and damage compared to controls that did not receive the } \\
\text { therapy }\end{array}$ & 123 \\
\hline Mouse & $\begin{array}{l}\text { IBD (IL-I0-deficient and } \\
\text { DSS-induced colitis models) }\end{array}$ & Lactobacillus salivarius & $\begin{array}{l}\text { Oral treatment with } L \text {. salivarius did not attenuate colitis } \\
\text { symptoms in IL-10-deficient or DSS-treated mice }\end{array}$ & 132 \\
\hline Mouse & $\begin{array}{l}\text { OVA-alum-driven model of } \\
\text { airway inflammation }\end{array}$ & Bifidobacterium longum & $\begin{array}{l}\text { Protected against airway inflammation in OVA-sensitized mice } \\
\text { and blocked induction of OVA-specific lgE }\end{array}$ & 66 \\
\hline Mouse & $\begin{array}{l}\text { OVA-alum-driven model of } \\
\text { airway inflammation }\end{array}$ & Lactobacillus reuteri, L. salivarius & $\begin{array}{l}\text { L. reuteri decreased airway hyperresponsiveness. L. salivarius } \\
\text { had no effect }\end{array}$ & 64 \\
\hline Human & Eczema & $\begin{array}{l}\text { Lactobacillus rhamnosus and } \\
\text { L. reuteri }\end{array}$ & $\begin{array}{l}\text { After } 6 \text { weeks of probiotic therapy, } 56 \% \text { of children (aged } \\
\text { I-I3 years) experienced improved eczema, while only I } 15 \% \\
\text { of placebo controls reported improved symptoms }\end{array}$ & 127 \\
\hline Human & UC & $\begin{array}{l}\text { Enema solution containing } \\
\text { L. reuteri }\end{array}$ & $\begin{array}{l}\text { Improved mucosal inflammation and decreased inflammatory } \\
\text { cytokines in children with UC }\end{array}$ & 128 \\
\hline Human & AR & L. johnsonii + levocetirizine & $\begin{array}{l}\text { Compared with patients receiving levocetirizine only, } \\
\text { L. johnsonii + levocetirizine improved AR symptoms including } \\
\text { increased IFN } \gamma \text { and IL-I0 and decreased IL- } 4 \text { concentrations, } \\
\text { and improved FVC and FEVI spirometry measurements in a } \\
24-\text { week, two-phase crossover treatment program }\end{array}$ & $|4|$ \\
\hline Human & Pollen allergy & B. longum & $\begin{array}{l}\text { Reduced ocular symptom scores during exposure to Japanese } \\
\text { cedar pollen }\end{array}$ & 142 \\
\hline Human & Peanut allergy & $\begin{array}{l}\text { L. rhamnosus + peanut oral } \\
\text { immunotherapy }\end{array}$ & $\begin{array}{l}\text { Subjects }(82.1 \%) \text { receiving combination peanut oral } \\
\text { immunotherapy }+L \text {. rhamnosus achieved possible sustained } \\
\text { unresponsiveness to peanut } 2-5 \text { weeks after discontinuation } \\
\text { of treatment compared to only } 3.6 \% \text { receiving placebo }\end{array}$ & 126 \\
\hline Human & $\begin{array}{l}A D \text {, recurrent wheeze, } \\
\text { allergic urticaria }\end{array}$ & scGOS + IcFOS & $\begin{array}{l}\text { Prebiotic group had significantly lower incidences of allergic } \\
\text { manifestations }\end{array}$ & 56 \\
\hline Human & $A D$ & $\begin{array}{l}\text { scGOS/lcFOS + B. breve } \\
\left(\text { Immunofortis }{ }^{\circledR}\right)\end{array}$ & $\begin{array}{l}\text { Increased galectin- } 9 \text { expression and reduced } A D \text { in infants } \\
\text { with IgE-mediated eczema } 12 \text { weeks posttreatment }\end{array}$ & 137 \\
\hline Human & Asthma & $\begin{array}{l}\text { scGOS/lcFOS + B. breve } \\
\text { (Immunofortis) }\end{array}$ & $\begin{array}{l}\text { Decreased prevalence of frequent wheezing and usage of } \\
\text { asthma medications in children with } A D \text { after I year follow- } \\
\text { up evaluation }\end{array}$ & 139 \\
\hline
\end{tabular}


Table 2 (Continued)

\begin{tabular}{|c|c|c|c|c|}
\hline & Disease & Treatment & Description of effects & Reference \\
\hline Human & $\begin{array}{l}\text { Asthma, eczema, allergic } \\
\text { rhinoconjunctivitis }\end{array}$ & L. reuteri & $\begin{array}{l}\text { Oral supplementation with L. reuteri ATCC } 55730 \text { in the } \\
\text { last month of gestation through the first year of life is not } \\
\text { associated with lower prevalence of allergic disease at } \\
7 \text { years of age }\end{array}$ & 130 \\
\hline Human & UC & $\begin{array}{l}\text { Escherichia coli Nissle } \\
\left.\text { (Mutaflor }^{\circledR}\right)\end{array}$ & $\begin{array}{l}\text { Mutaflor }{ }^{\circledR} \text { is as effective at preventing relapses as the } \\
\text { established mesalazine therapy in patients with UC. Patients } \\
\text { (36.4\%) receiving Mutaflor for } 12 \text { months experienced } \\
\text { relapses compared to } 33.9 \% \text { in the mesalazine group }\end{array}$ & 129 \\
\hline Human & UC & $\begin{array}{l}\text { Inulin-oligofructose } \\
\left(\text { Synergy }{ }^{\circledR} \mathrm{I}\right)+\text { B. longum }\end{array}$ & $\begin{array}{l}\text { Reduced chronic inflammatory markers of UC (TNF } \alpha \text { and } \\
I L-I \alpha)\end{array}$ & 140 \\
\hline
\end{tabular}

Abbreviations: HLA, human leukocyte antigen; FOS, fructooligosaccharide; TID, type I diabetes; BB-DP, bio-breeding diabetes-prone; NOD, non-obese diabetic; IFN, interferon; IL, interleukin; OVA, ovalbumin; alum, potassium aluminum sulfate; SCFA, short-chain fatty acid; DSS, dextran sulfate sodium; scGOS, short-chain galactooligosaccharide; IcFOS, long-chain fructooligosaccharide; PAOS, pectin-derived acidic oligosaccharide; CMA, cow's milk allergy; GLP, glucagon-like peptide; UC, ulcerative colitis; STZ, streptozotocin; SPF, specific pathogen-free; GF, germ-free; AD, atopic dermatitis; AR, allergic rhinitis; HDM, house dust mite; IBD, inflammatory bowel disease; FVC, forced expiratory vital capacity; FEVI, forced expiratory volume in I second; ATCC, American Type Culture Collection; Ig, immunoglobulin.

of the importance of the intestinal microbiota for mammalian immune development comes from studies conducted in germfree (GF) mice, in which the lack of a microbiota results in reduced Peyer's patches, smaller germinal centers and fewer plasma cells, and increased susceptibility to pathogen invasion when compared to conventionally raised mice. ${ }^{35-38}$ Although GF murine models are valuable in mechanistic studies, they do have many caveats. ${ }^{39}$ To fully elucidate the underlying mechanisms driving the relationship of the gut microbiota with atopic disease development, many different murine models, including GF, gnotobiotic, and antibiotic-treated models, along with models supplemented with specific bacterial species, should be used. In addition, murine systems with a reconstituted human immune system would be even more valuable.

Specific bacterial species within the microbiota have been shown to induce expression of antimicrobial peptides (eg, Bacteroides thetaiotaomicron induction of regenerating islet-derived $3 \gamma$ expression by Paneth cells) and mucin production, which ultimately confers protection against pathogen invasion, and combined with regular stimulation of pattern recognition receptors, contributes to intestinal homeostasis. ${ }^{40-42}$ The presence of the microbiota can stimulate $\mathrm{CD}^{+} \mathrm{T}$-cell proliferation, Th17 cell differentiation through the induction of IL-1 $\beta$, and accumulation of colonic Tregs. ${ }^{43-45}$ The intestinal microbiota also metabolizes food components that are indigestible by mammalian enzymes, such as human milk oligosaccharides (HMOs) and dietary fiber. ${ }^{46,47}$ This produces short-chain fatty acids (SCFAs), which are essential energy sources for many host tissues and prominent immune modulators. ${ }^{48-50}$ There are many factors that likely contribute to the development of immune dysregulation: perturbations to the composition of the intestinal microbiota, caused by environmental factors such as antibiotic exposure, birth mode, or diet, are one potential explanation linking early life hygiene with the development of atopic and immune-mediated disorders (Figure 2).

\section{The intestinal microbiota in atopic disease: human studies}

A longitudinal study comparing the early life intestinal microbiota compositions of school-age asthmatic and non-asthmatic children showed that significant decreases in overall gut microbial diversity at 1 week and 1 month of age were correlated with asthma development at school age. ${ }^{51}$ Additionally, a recent characterization of the gut microbiota of 166 Canadian infants revealed an increased Enterobacteriaceae/Bacteroidaceae ratio in children sensitized to food allergens at 3 months and 1 year of age compared to non-sensitized children. ${ }^{52}$ Also, lower gut microbial richness was observed at 3 months of age only. ${ }^{52}$ Studies such as these suggest that therapeutic microbial intervention early in human life may be favorable, and highlight the need for animal studies in which experimentation to confirm causality is possible.

Many human studies lend support for the hygiene and microflora hypotheses by assessing the impact of early life environmental factors known to disturb the intestinal microbiota on atopic disease development later in life. For example, antibiotic usage in the first 2 years of life has been associated with the development of asthma at 7.5 years of age in a dose-dependent manner. ${ }^{53}$ Additionally, antibiotic usage was reported to precede the manifestation of wheeze in the first 2 years of life in a questionnaire-based analysis of the KOALA (acronym in Dutch for "Child, parents and health: lifestyle and genetic constitution") Birth Cohort 


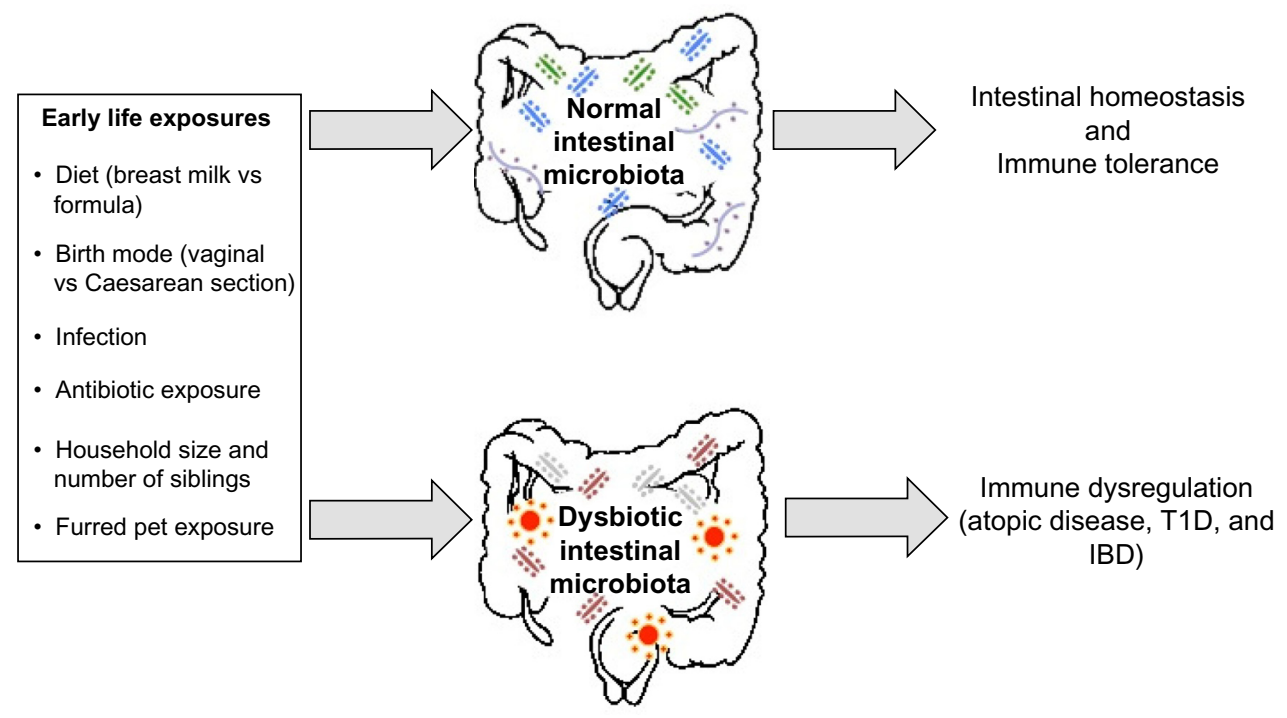

Figure 2 A depiction of the early life environmental exposures differentially associated with promoting a healthy intestinal microbiota, which results in intestinal homeostasis and immune tolerance, and a dysbiotic (unhealthy) intestinal microbiota, which may induce the development of immune dysregulation.

Abbreviations: vs, versus; TID, type I diabetes; IBD, inflammatory bowel disease.

Study in the Netherlands. ${ }^{54}$ Birth by Caesarean section was associated with lower total microbial diversity, delayed colonization with Bacteroidetes, and decreased Th1 responses in the first 2 years of life. ${ }^{55}$ Breastfeeding promotes colonization with commensal microbes such as Bifidobacteria spp. and provides the intestinal microbiota with necessary nutrients in the form of HMOs. ${ }^{46,56}$ Specific HMOs, short-chain galactooligosaccharides (GOSs) and long-chain fructooligosaccharides (FOSs), administered in the first 6 months of life have been shown to reduce the cumulative incidences of $\mathrm{AD}$, recurrent wheezing, and allergic urticaria. ${ }^{57}$ In line with Strachan's original proposal, one study found that an increased number of older siblings was associated with decreased colonization with Clostridium difficile and Clostridium cluster 1, and a decreased risk of developing AD. ${ }^{58}$ Correlative human studies such as these shed light on the environmental factors that may be associated with atopic disease through manipulation of the intestinal microbiota; however, research regarding factors such as antibiotic exposure, breastfeeding, and birth mode remains controversial, and there are studies that suggest these factors have little or no effect on atopic disease development. ${ }^{59-64}$ Additional longitudinal human studies are necessary to determine which early life factors are most influential in promoting the intestinal dysbiosis associated with the development of immune hypersensitivities, and animal model research is a crucial complementary approach to elucidate the mechanisms behind these associations.

\section{The intestinal microbiota in atopic disease: mouse models}

Murine model studies mechanistically support a link between the intestinal microbiota and atopic disorders through the experimental manipulation of microbiota compositions. In an OVA-driven model of asthma, Forsythe et al show that oral supplementation with live Lactobacillus reuteri reduced airway hyperresponsiveness as well as levels of TNFalpha, monocyte chemotactic protein 1, IL-5, and IL-13 in the bronchoalveolar lavage fluid (BALF), while treatment with Lactobacillus salivarius had no effect. ${ }^{65}$ Intranasal supplementation of mice, polysensitized to birch and grass pollen allergens, with Bifidobacterium longum and Lactobacillus paracase $i$ at the time of sensitization resulted in reduced IgE-dependent basophil degranulation in response to allergen challenge ${ }^{66}$ Only $B$. longum displayed protective effects when mice were supplemented prior to allergen sensitization. ${ }^{66}$ Additionally, oral supplementation of mice with B. longum protected against airway inflammation, increased Peyer's patch and splenic Tregs, and blocked serum IgE induction in OVA-sensitized animals. ${ }^{67}$

More recent research focuses on the earliest time point at which gut microbial intervention must occur to prevent the onset of hypersensitivity disease. In an OVA-driven model of allergic inflammation, neonatal (but not adult) exposure of previously GF mice to a conventional microbiota reduced the severity of allergic inflammation characterized by decreased accumulation of invariant natural killer (NK) T-cells to the lung and reduced serum IgE levels and eosinophil frequencies 
in the BALF. ${ }^{68}$ Arnold et al show in OVA- and HDM-driven mouse models of allergic inflammation that oral infection of neonatal mice with $H$. pylori prior to OVA or HDM challenge resulted in the significant reduction of eosinophils in the BALF, and a decrease in IL-5 and IL-13 cytokine levels when compared to uninfected mice and infected adult mice. ${ }^{69}$ Russell et al found that perinatal vancomycin treatment of OVA-challenged mice alters gut microbial composition and exacerbates asthma-related immune responses, which may be driven by increased serum IgE levels and reduced Treg populations. ${ }^{70}$ Interestingly, perinatal treatment with streptomycin did not result in exacerbated disease after OVA challenge, but perinatally streptomycin-treated mice showed exaggerated lung inflammation when compared to untreated or vancomycin-treated mice in a Th1/Th17-driven model of hypersensitivity pneumonitis. ${ }^{70,71}$ This highlights the ability of altered microbiota compositions to differentially control disease severity depending on the immunological basis of the disease. ${ }^{71}$ Additional studies including human subjects and supporting mechanistic animal models are necessary to provide a holistic view of the role of the intestinal microbiota in atopic disease. Currently, there is also increasing evidence supporting a role of the intestinal microbiota and early life environmental exposures in other immune-mediated disorders. ${ }^{72}$ For the purpose of this review, we focus on IBD and T1D.

\section{The hygiene and microflora hypotheses and immune- mediated disorders IBD}

IBD is an inflammatory disorder of the gastrointestinal (GI) tract encompassing Crohn's disease (CD) and ulcerative colitis (UC), both of which are highest in prevalence in North America and Europe. ${ }^{73}$ The presence of intestinal bacteria appears to be required for the development of experimental colitis, while the composition influences the severity of IBD. GF IL-10-deficient mice show no evidence of experimental colitis, while IL-10-deficient mice housed under specific pathogen-free (SPF) conditions spontaneously develop the disease. ${ }^{74}$ Additionally, antibiotics have been shown to attenuate the symptoms of experimental colitis. ${ }^{75-77}$ Exposure of SPF IL-10-deficient mice to antibiotics displays differential and localized roles of specific bacteria in mediating experimental colitis. ${ }^{77}$ For example, treatment of SPF IL-10deficient mice with vancomycin-imipenem and metronidazole eliminated anaerobic bacteria and reduced colonic injury, while ciprofloxacin and vancomycin-imipenem decreased cecal inflammation and reduced the prevalence of Escherichia coli and Enterococcus faecalis. ${ }^{77}$

Some human studies suggest that early life antibiotic exposure is associated with IBD. ${ }^{78-80}$ This discrepancy is likely because antibiotics in murine IBD experiments are typically given as treatment after disease onset, whereas human studies are often retrospective and assess the effects of antibiotic exposure prior to disease onset. In a nested casecontrol study, children diagnosed with IBD at approximately 8 years of age were 2.9 times more likely to have received antibiotics in the first year of life. ${ }^{80}$ Additionally, antibiotic exposure in the first 3 months of life was associated with childhood CD. ${ }^{79}$ Conversely, antibiotic combination therapy has been shown to be effective in treating UC in humans. ${ }^{81}$ Thus, effects after antibiotic exposure in humans are likely disease specific and/or dependent on when antibiotics are administered (ie, before or after disease onset).

Diet may also play an important role in IBD. Maternal secretory IgA (a component of breast milk) has been shown to alter the intestinal microbiota composition and the expression of genes associated with intestinal inflammation. ${ }^{82}$ Additionally, a systematic review negatively correlated breast milk exposure with the development of early onset IBD in humans, suggesting a protective effect of breastfeeding on IBD development. ${ }^{83}$

Altogether, these results suggest that IBD is driven by the composition of the intestinal microbiota, which is strongly influenced by early life environmental factors. Early life diet (breastfeeding) is likely protective against IBD development, while effects of antibiotic exposure are more complicated. If antibiotics are given in early life, they may result in an intestinal microbiota that promotes IBD development. ${ }^{79,80}$ However, after disease onset, antibiotics alleviate disease severity by shifting the prevalence of specific microbes that may be promoting the disease. ${ }^{75-77,79,81}$ Regardless, factors related to early life hygiene are involved in IBD development, and there is also evidence that the hygiene and microflora hypotheses are applicable to immune-mediated disorders not associated with the GI tract, such as T1D. ${ }^{84-96}$

\section{TID}

The prevalence of childhood T1D, an autoimmune disorder resulting from T-cell mediated destruction of beta cells in the pancreas, is steadily increasing worldwide, and developed countries such as Canada and the UK exhibit the highest incidences of the disease. ${ }^{84,85}$ Epidemiological evidence supports a link between environmental factors associated with 
the hygiene hypothesis and the onset of T1D. Having older siblings is negatively correlated with childhood onset T1D, suggesting a protective effect. ${ }^{86}$ Furred pet exposure seems to also play a role, as one study found in a birth cohort of 3,000 children: children exposed to an indoor dog were less likely to develop T1D than unexposed children. ${ }^{87}$ Breastfeeding has been associated with protection from T1D, and children born by Caesarean section exhibit a higher risk of T1D than children born vaginally. ${ }^{88-90}$

Lending support for the microflora hypothesis, a recent study compared the gut microbial compositions of children with T1D and healthy children and concluded that children with T1D showed a significant increase in Bacteroides spp., which was later reduced to that of controls after insulin treatment for 2 years..$^{91}$ Oral administration of Lactobacillus johnsonii isolated from bio-breeding (BB) diabetes-resistant rats was shown to delay the onset of T1D in BB-diabetes prone rats. ${ }^{92}$ Additionally, MyD88-deficient NOD mice are protected from disease onset in SPF environments, and segmented filamentous bacteria have been reported to protect female NOD mice from disease development. ${ }^{93,94}$ Additionally, antibiotic therapy in mice has been shown to protect against virus-induced T1D through the alteration of intestinal microbiota composition. ${ }^{95}$ However, in humans the contribution of antibiotics to T1D development is currently unclear, as a population-based human cohort study found no association between T1D and antibiotic exposure in the first 8 years of life. ${ }^{96}$ Thus, similar to atopic disease and IBD, early life factors common to industrialized countries such as birth mode, diet, and antibiotic exposure seem to play a role in T1D development. However, additional mechanistic research is needed before significant conclusions regarding the gut microbial composition and immunological consequences can be made. The use of appropriate animal models will be critical in continuing to determine whether the relationship between microbiota composition and immune dysregulation is causal, or an effect of a dysregulated immune environment. Regardless, research related to the hygiene, old friends, and microflora hypotheses supports early life intervention as the primary therapeutic component for averting immune dysregulation in the form of atopic and immune-mediated disorders.

\section{Future therapeutics}

Future therapeutic options to prevent the development of immune dysregulation will likely involve the millions of micro- and macroorganisms living commensally or symbiotically (microbiota), or even parasitically (helminths) in the human body. In this section, we discuss potential helminthbased (Table 1) and microbiota-based therapies (Table 2) in the prevention of these disorders.

\section{Helminth-based therapies}

Clinical trials to date have focused on the use of live helminth infection as an ameliorative, rather than preventative, strategy due to the potential for diminished vaccine responsiveness in mice and humans infected with helminths early in life. ${ }^{97-101}$ The majority of early phase clinical trials to determine the safety and efficacy of live helminth infection have been conducted in CD and UC patients. ${ }^{102}$ Initial clinical trials using ova from the porcine whipworm, Trichuris suis, or larvae from the human hookworm, Necator americanus, have not yet found any cause for major safety concerns in IBD or asthma patients. ${ }^{103-107}$ T. suis ova administration seemed to reduce intestinal inflammation in a small number of CD and UC patients, and administration of $N$. americanus larvae to $\mathrm{CD}$ patients resulted in a nonsignificant improvement in intestinal inflammation scores. ${ }^{104-108}$ These initial clinical trials were promising, although follow-up studies with the inclusion of placebo control groups show mixed results. ${ }^{102,107,108}$

Live helminth parasites release a suite of ES immunomodulatory products that likely mediate many of their suppressive effects in models of allergic disease and experimental colitis. ${ }^{109}$ In mice exposed to both OVA- and Alternaria alternata-driven asthma models, administration of ES material from the murine intestinal nematode, $H$. polygyrus (HES), was sufficient to suppress lung eosinophilia and histopathology in response to antigen challenge. ${ }^{110,111}$ HES appears to suppress lung inflammation when given at the point of antigen sensitization and antigen challenge, making it a promising therapeutic candidate. ${ }^{110}$ Soluble products from several different helminth parasites have also been shown to reduce measures of disease severity in murine models of trinitrobenzene sulfonic acid-induced and dextran sulfate sodium-induced colitis and T1D. ${ }^{112-116}$ Administration of helminth ES products rather than live helminths has not yet begun in human patients, but evidence from murine models suggests that this is a promising approach for future clinical trials.

Researchers are beginning to elucidate the mechanisms that mediate the potent immunoregulatory effects of these helminth products. ES products from $N$. americanus mediate the rapid proteolysis of eotaxin, an eosinophil chemoattractant, and HES can stimulate the induction of Tregs through a TGF$\beta$-dependent pathway. ${ }^{117,118}$ Whether the administration of helminth products modifies the composition of the intestinal 
microbiota is not yet reported. However, infection of mice with live helminth parasites results in a marked disruption of intestinal microbiota composition, suggesting that the immunosuppressive effects following helminth infection could be due to an indirect modulation of the microbiota. ${ }^{19-121}$ The relative contribution of the microbiota or helminth-secreted products in ameliorating immune dysregulation remains to be determined. If microbiota compositional shifts following helminth infection are shown to have a direct role in disease modulation, future probiotic administration to drive the microbiota composition toward that seen during helminth infection may be a novel therapeutic approach.

\section{Microbiota-based therapies}

Probiotics are live bacteria which, when administered, are beneficial to host health. Animal model research using probiotics shows their ability to ameliorate symptoms in atopic disease, IBD, and T1D. ${ }^{66,92,119,122-125}$ Additionally, probiotic administration in humans has been shown to protect against allergic rhinitis, peanut allergy, AD, and UC. ${ }^{124,126-129}$ However, research thus far reveals many gaps in probiotic therapy, likely due to individualized disease phenotypes that may or may not be linked to the specific microbial species tested. ${ }^{130-132}$ Consequently, prebiotic and synbiotic therapeutics are also being explored.

Prebiotics are chemicals or food components (eg, inulin, pectin, GOSs, and FOSs), which are indigestible by pancreatic and intestinal enzymes, but are important in the growth and proliferation of intestinal microbiota. ${ }^{133}$ Prebiotic substances can induce the production of SCFAs by intestinal microbes, which have been shown to promote effector (Th1 and Th17) and anti-inflammatory IL-10-producing FoxP3 ${ }^{+}$ and non-FoxP3 ${ }^{+}$T-cell differentiation. ${ }^{48,49}$ As such, they continue to be a promising microbe-based therapeutic option to modulate intestinal immune responses. Supplementation of mice with a mixture of short-chain GOS, long-chain GOS, and pectin-derived acidic oligosaccharides prior to OVA challenge suppressed airway inflammation and hyperresponsiveness compared to controls. ${ }^{134}$ Additionally, Trompette et al show that a high-fiber diet (diet supplemented with $30 \%$ pectin) metabolized by the gut microbiota increases the concentrations of circulating SCFAs and decreases allergic inflammation in the lungs of an HDM-driven model of allergic inflammation. ${ }^{47}$ In humans, prebiotic oligosaccharide formula supplementation in the first 6 months of life has been associated with decreased incidences of allergic manifestations until 2 years of age, supporting early life intervention in humans. ${ }^{57}$ Additionally, prebiotics have been implicated in protection from IBD development. Human leukocyte antigen-B27 transgenic (HLA-B27, TG) rats supplemented with FOS and inulin prior to disease onset showed decreased intestinal inflammation compared to untreated rats; however, FOS-treated rats compared to inulin-treated rats showed less intestinal inflammation, suggesting FOS as a more effective prebiotic treatment for spontaneous colitis. ${ }^{135}$ Conversely, FOS was not an effective treatment for $\mathrm{CD}$, as patients receiving the treatment after 4 weeks exhibited higher GI symptoms compared to the placebo group, despite the reduced IL-6 and increased IL-10 production from lamina propria dendritic cells. ${ }^{136}$

Synbiotic therapies involve supplementation with both pre- and probiotics. In a murine model for cow's milk allergy, mice fed the synbiotic mixture (GOS, FOS, and Bifidobacterium breve $\mathrm{M}-16 \mathrm{~V}$ ) showed increased galectin-9 expression by intestinal epithelial cells, which correlated with reduced acute skin reaction and mast cell degranulation. ${ }^{137}$ Similar results were measured in humans fed the synbiotic mixture, suggesting a mechanism by which this therapy may be effective in protecting against AD in humans. ${ }^{137}$ Conversely, a clinical trial using a similar synbiotic mixture, Immunofortis $^{\circledR}$, found no difference in AD severity in the synbiotic group versus the placebo group. ${ }^{138}$ However, this research group did later find in infants with $\mathrm{AD}$ that supplementation with this mixture for 12 weeks correlated with decreased prevalence of wheezing and asthma medication usage after 1 year. ${ }^{139}$ Synbiotics are also potential therapeutics for IBD. In a controlled pilot trial involving 18 patients with active UC, short-term synbiotic therapy combining B. longum and inulin-oligofructose significantly reduced chronic inflammatory biomarkers of the disease, including decreased TNF $\alpha$ and IL- $1 \alpha$ levels. ${ }^{140}$

The effects of early life factors such as diet and antibiotic exposure discussed throughout this review suggest that the application of live helmiths/helminth ES products, and pro-, pre-, and synbiotics prior to disease onset may be key in averting disease development, because interventions occurring later in life or after disease onset may be ineffective after the neonatal immune developmental window has closed. The timing of this developmental window could be driven by epigenetic alterations to specific, microbially regulated factors, such as the CXCL16 gene described by Olszak et al. ${ }^{68}$ In previously GF mice colonized neonatally with a conventional microbiota, the presence of a conventional microbiota decreased hypermethylation of CXCL16, which consequently decreased accumulation of invariant NK T-cells in the colon (this did not occur in previously GF mice colonized until 
they reached adulthood). This suggests that microbe-based therapeutics aimed at protecting against hyperinflammatory diseases are age-sensitive. ${ }^{67}$ Additionally, the incongruity of current research highlights the need for future microbiotabased treatments that are constructed as individualized therapeutics specific to the disease phenotype and microbiota of the affected patient.

\section{Conclusion}

The progression of research since Strachan's 1989 proposal of the hygiene hypothesis exemplifies the scientific method in health research, progressing from observational theory to experimental therapy. The hygiene hypothesis has been expanded today to include commensal and symbiotic intestinal microbes, which are profoundly involved in human immune development, and parasitic helminths, which are also strong therapeutic candidates to protect against immune dysregulation. More research addressing the early life "critical window" for microbiota intervention, currently being assessed in mice for hypersensitivity diseases, is needed if researchers hope to use these therapeutics to prevent immune dysregulation in humans. ${ }^{68-71}$ Children undergo large shifts in their intestinal microbiota compositions throughout the first few months of life; thus, it may be possible in the near future to shift the gut microbial composition using pro-, pre-, and synbiotics toward a microbiota that promotes immune tolerance. ${ }^{72}$

\section{Acknowledgments}

LT Stiemsma is supported by the University of British Columbia Four-Year Fellowship. SET holds the Aubrey J Tingle Professorship in Pediatric Immunology and is a clinical scholar of the Michael Smith Foundation for Health Research. Work in the Finlay and Turvey labs is supported by a Canadian Institutes of Health Research (CIHR) Emerging Team Grant in partnership with Genome BC and AllerGen NCE, the Allergy, Genes and Environment Network.

\section{Disclosure}

The authors report no conflicts of interest in this work.

\section{References}

1. [No authors listed]. Worldwide variation in prevalence of symptoms of asthma, allergic rhinoconjunctivitis, and atopic eczema: ISAAC. The International Study of Asthma and Allergies in Childhood (ISAAC) Steering Committee. Lancet. 1998;351(9111):1225-1232.

2. Anandan C, Nurmatov U, van Schayck OC, Sheikh A. Is the prevalence of asthma declining? Systematic review of epidemiological studies. Allergy. 2010;65(2):152-167.

3. Okada H, Kuhn C, Feillet H, Bach JF. The 'hygiene hypothesis' for autoimmune and allergic diseases: an update. Clin Exp Immunol. 2010; 160(1):1-9.
4. Brooks C, Pearce N, Douwes J. The hygiene hypothesis in allergy and asthma: an update. Curr Opin Allergy Clin Immunol. 2013;13(1): $70-77$.

5. Greenwood BM. Polyarthritis in Western Nigeria. I. Rheumatoid arthritis. Ann Rheum Dis. 1969;28(5):488-496.

6. Greenwood BM, Herrick EM, Voller A. Suppression of autoimmune disease in NZB and (NZB x NZW) F1 hybrid mice by infection with malaria. Nature. 1970;226(5242):266-267.

7. Gerrard JW, Geddes CA, Reggin PL, Gerrard CD, Horne S. Serum IgE levels in white and metis communities in Saskatchewan. Ann Allergy. 1976;37(2):91-100.

8. Strachan DP. Hay fever, hygiene, and household size. BMJ. 1989; 299(6710):1259-1260.

9. Strachan DP, Taylor EM, Carpenter RG. Family structure, neonatal infection, and hay fever in adolescence. Arch Dis Child. 1996;74(5): $422-426$.

10. Ownby DR, Johnson CC, Peterson EL. Exposure to dogs and cats in the first year of life and risk of allergic sensitization at 6 to 7 years of age. JAMA. 2002;288(8):963-972.

11. Benn CS, Melbye M, Wohlfahrt J, Björkstén B, Aaby P. Cohort study of sibling effect, infectious diseases, and risk of atopic dermatitis during first 18 months of life. BMJ. 2004;328(7450):1223.

12. Matricardi PM, Rosmini F, Riondino S, et al. Exposure to foodborne and orofecal microbes versus airborne viruses in relation to atopy and allergic asthma: epidemiological study. BMJ. 2000;320(7232):412-417.

13. Ege MJ, Mayer M, Normand AC, et al; GABRIELA Transregio 22 Study Group. Exposure to environmental microorganisms and childhood asthma. N Engl J Med. 2011;364(8):701-709.

14. Mosmann TR, Cherwinski H, Bond MW, Giedlin MA, Coffman RL. Two types of murine helper T cell clone. I. Definition according to profiles of lymphokine activities and secreted proteins. J Immunol. 1986;136(7):2348-2357.

15. Bosnjak B, Stelzmueller B, Erb KJ, Epstein MM. Treatment of allergic asthma: modulation of Th2 cells and their responses. Respir Res. 2011;12:114.

16. Huang L, Krieg AM, Eller N, Scott DE. Induction and regulation of Th1-inducing cytokines by bacterial DNA, lipopolysaccharide, and heat-inactivated bacteria. Infect Immun. 1999;67(12):6257-6263.

17. Oriss TB, McCarthy SA, Morel BF, Campana MA, Morel PA. Crossregulation between $\mathrm{T}$ helper cell (Th)1 and Th2: inhibition of Th2 proliferation by IFN-gamma involves interference with IL-1. J Immunol. 1997;158(8):3666-3672.

18. Maizels RM, McSorley HJ, Smyth DJ. Helminths in the hygiene hypothesis: sooner or later? Clin Exp Immunol. 2014;177(1):38-46.

19. O'Shea JJ, Paul WE. Mechanisms underlying lineage commitment and plasticity of helper CD4+ T cells. Science. 2010;327(5969): 1098-1102.

20. Lloyd CM, Saglani S. T cells in asthma: influences of genetics, environment, and T-cell plasticity. J Allergy Clin Immunol. 2013;131(5): 1267-1274; quiz 1275.

21. Holgate ST. Innate and adaptive immune responses in asthma. Nat Med. 2012;18(5):673-683.

22. Rook GA, Adams V, Hunt J, Palmer R, Martinelli R, Brunet LR. Mycobacteria and other environmental organisms as immunomodulators for immunoregulatory disorders. Springer Semin Immunopathol. 2004;25(3-4):237-255.

23. Noverr MC, Huffnagle GB. The 'microflora hypothesis' of allergic diseases. Clin Exp Allergy. 2005;35(12):1511-1520.

24. Rook GA, Brunet LR. Microbes, immunoregulation, and the gut. Gut. 2005;54(3):317-320.

25. van den Biggelaar AH, van Ree R, Rodrigues LC, et al. Decreased atopy in children infected with Schistosoma haematobium: a role for parasite-induced interleukin-10. Lancet. 2000;356(9243):1723-1727.

26. Wilson MS, Taylor MD, Balic A, Finney CAM, Lamb JR, Maizels RM. Suppression of allergic airway inflammation by helminth-induced regulatory T cells. J Exp Med. 2005;202(9):1199-1212. 
27. Kitagaki K, Businga TR, Racila D, Elliott DE, Weinstock JV, Kline JN. Intestinal helminths protect in a murine model of asthma. J Immunol. 2006;177(3):1628-1635.

28. Mangan NE, Fallon RE, Smith P, van Rooijen N, McKenzie AN, Fallon PG. Helminth infection protects mice from anaphylaxis via IL-10producing B cells. J Immunol. 2004;173(10):6346-6356.

29. Liu Q, Sundar K, Mishra PK, et al. Helminth infection can reduce insulitis and type 1 diabetes through CD25- and IL-10-independent mechanisms. Infect Immun. 2009;77(12):5347-5358.

30. Mishra PK, Patel N, Wu W, Bleich D, Gause WC. Prevention of type 1 diabetes through infection with an intestinal nematode parasite requires IL-10 in the absence of a Th2-type response. Mucosal Immunol. 2013;6(2):297-308.

31. Hübner MP, Stocker JT, Mitre E. Inhibition of type 1 diabetes in filaria-infected non-obese diabetic mice is associated with a $\mathrm{T}$ helper type 2 shift and induction of FoxP3+ regulatory T cells. Immunology. 2009;127(4):512-522.

32. Hübner MP, Shi Y, Torrero MN, et al. Helminth protection against autoimmune diabetes in nonobese diabetic mice is independent of a type 2 immune shift and requires TGF-beta. J Immunol. 2012;188(2): $559-568$.

33. McSorley HJ, Maizels RM. Helminth infections and host immune regulation. Clin Microbiol Rev. 2012;25(4):585-608.

34. O'hara AM, Shanahan F. The gut flora as a forgotten organ. Embo Reports. 2006;7(7):688-693.

35. Pollard M, Sharon N. Responses of the Peyer's patches in germ-free mice to antigenic stimulation. Infect Immun. 1970;2(1):96-100.

36. Round JL, Mazmanian SK. The gut microbiota shapes intestinal immune responses during health and disease. Nat Rev Immunol. 2009;9(5): 313-323.

37. Fagundes CT, Amaral FA, Vieira AT, et al. Transient TLR activation restores inflammatory response and ability to control pulmonary bacterial infection in germfree mice. J Immunol. 2012;188(3):1411-1420.

38. Inagaki H, Suzuki T, Nomoto K, Yoshikai Y. Increased susceptibility to primary infection with Listeria monocytogenes in germfree mice may be due to lack of accumulation of L-selectin + CD44+ T cells in sites of inflammation. Infect Immun. 1996;64(8):3280-3287.

39. Yi P, Li L. The germfree murine animal: an important animal model for research on the relationship between gut microbiota and the host. Vet Microbiol. 2012;157(1-2):1-7.

40. Cash HL, Whitham CV, Behrendt CL, Hooper LV. Symbiotic bacteria direct expression of an intestinal bactericidal lectin. Science. 2006;313(5790):1126-1130.

41. Lindén SK, Florin TH, McGuckin MA. Mucin dynamics in intestinal bacterial infection. PLoS One. 2008;3(12):e3952.

42. Rakoff-Nahoum S, Paglino J, Eslami-Varzaneh F, Edberg S, Medzhitov R. Recognition of commensal microflora by toll-like receptors is required for intestinal homeostasis. Cell. 2004;118(2):229-241.

43. Cording S, Fleissner D, Heimesaat MM, et al. Commensal microbiota drive proliferation of conventional and Foxp3(+) regulatory CD4(+) T cells in mesenteric lymph nodes and Peyer's patches. Eur J Microbiol Immunol (Bp). 2013;3(1):1-10.

44. Shaw MH, Kamada N, Kim YG, Núñez G. Microbiota-induced IL-1beta, but not IL-6, is critical for the development of steady-state TH17 cells in the intestine. $J$ Exp Med. 2012;209(2):251-258.

45. Atarashi K, Tanoue T, Shima T, et al. Induction of colonic regulatory T cells by indigenous Clostridium species. Science. 2011;331(6015): 337-341.

46. Marcobal A, Barboza M, Froehlich JW, et al. Consumption of human milk oligosaccharides by gut-related microbes. J Agric Food Chem. 2010;58(9):5334-5340.

47. Trompette A, Gollwitzer ES, Yadava K, et al. Gut microbiota metabolism of dietary fiber influences allergic airway disease and hematopoiesis. Nat Med. 2014;20(2):159-166.

48. Wong JM, de Souza R, Kendall CW, Emam A, Jenkins DJ. Colonic health: fermentation and short chain fatty acids. J Clin Gastroenterol. 2006;40(3):235-243.
49. Park J, Kim M, Kang SG, et al. Short-chain fatty acids induce both effector and regulatory $\mathrm{T}$ cells by suppression of histone deacetylases and regulation of the mTOR-S6K pathway. Mucosal Immunol. 2015;8(1): $80-93$.

50. Smith PM, Howitt MR, Panikov N, et al. The microbial metabolites, short-chain fatty acids, regulate colonic Treg cell homeostasis. Science. 2013;341(6145):569-573

51. Abrahamsson TR, Jakobsson HE, Andersson AF, Björkstén B, Engstrand L, Jenmalm MC. Low gut microbiota diversity in early infancy precedes asthma at school age. Clin Exp Allergy. 2014;44(6):842-850.

52. Azad MB, Konya T, Guttman DS, et al; CHILD Study Investigators. Infant gut microbiota and food sensitization: associations in the first year of life. Clin Exp Allergy. 2015;45(3):632-643.

53. Hoskin-Parr L, Teyhan A, Blocker A, Henderson AJ. Antibiotic exposure in the first two years of life and development of asthma and other allergic diseases by $7.5 \mathrm{yr}$ : a dose-dependent relationship. Pediatr Allergy Immunol. 2013;24(8):762-771.

54. Kummeling I, Stelma FF, Dagnelie PC, et al. Early life exposure to antibiotics and the subsequent development of eczema, wheeze, and allergic sensitization in the first 2 years of life: the KOALA Birth Cohort Study. Pediatrics. 2007;119(1):e225-e231.

55. Jakobsson HE, Abrahamsson TR, Jenmalm MC, et al. Decreased gut microbiota diversity, delayed Bacteroidetes colonisation and reduced Th1 responses in infants delivered by caesarean section. Gut. 2014;63(4):559-566.

56. Penders J, Thijs C, Vink C, et al. Factors influencing the composition of the intestinal microbiota in early infancy. Pediatrics. 2006;118(2): 511-521.

57. Arslanoglu S, Moro GE, Schmitt J, Tandoi L, Rizzardi S, Boehm G. Early dietary intervention with a mixture of prebiotic oligosaccharides reduces the incidence of allergic manifestations and infections during the first two years of life. $J$ Nutr. 2008;138(6):1091-1095.

58. Penders J, Gerhold K, Stobberingh EE, et al. Establishment of the intestinal microbiota and its role for atopic dermatitis in early childhood. $J$ Allergy Clin Immunol. 2013;132(3):601-607. e8.

59. Mullooly JP, Schuler R, Barrett M, Maher JE. Vaccines, antibiotics, and atopy. Pharmacoepidemiol Drug Saf. 2007;16(3):275-288.

60. Ortqvist AK, Lundholm C, Kieler H, et al. Antibiotics in fetal and early life and subsequent childhood asthma: nationwide population based study with sibling analysis. BMJ. 2014;349:g6979.

61. Sears MR, Greene JM, Willan AR, et al. Long-term relation between breastfeeding and development of atopy and asthma in children and young adults: a longitudinal study. Lancet. 2002;360(9337): 901-907.

62. Almqvist C, Cnattingius S, Lichtenstein P, Lundholm C. The impact of birth mode of delivery on childhood asthma and allergic diseases a sibling study. Clin Exp Allergy. 2012;42(9):1369-1376.

63. Maitra A, Sherriff A, Strachan D, Henderson J, Team AS. Mode of delivery is not associated with asthma or atopy in childhood. Clin Exp Allergy. 2004;34(9):1349-1355.

64. Kramer MS, Matush L, Vanilovich I, et al; Promotion of Breastfeeding Intervention Trial (PROBIT) Study Group. Effect of prolonged and exclusive breast feeding on risk of allergy and asthma: cluster randomised trial. BMJ. 2007;335(7624):815.

65. Forsythe P, Inman MD, Bienenstock J. Oral treatment with live Lactobacillus reuteri inhibits the allergic airway response in mice. Am J Respir Crit Care Med. 2007;175(6):561-569.

66. Schabussova I, Hufnagl K, Wild C, et al. Distinctive anti-allergy properties of two probiotic bacterial strains in a mouse model of allergic poly-sensitization. Vaccine. 2011;29(10):1981-1990.

67. Lyons A, O'Mahony D, O'Brien F, et al. Bacterial strain-specific induction of Foxp3+T regulatory cells is protective in murine allergy models. Clin Exp Allergy. 2010;40(5):811-819.

68. Olszak T, An D, Zeissig S, et al. Microbial exposure during early life has persistent effects on natural killer T cell function. Science. 2012; 336(6080):489-493. 
69. Arnold IC, Dehzad N, Reuter S, et al. Helicobacter pylori infection prevents allergic asthma in mouse models through the induction of regulatory T cells. J Clin Invest. 2011;121(8):3088-3093.

70. Russell SL, Gold MJ, Willing BP, Thorson L, McNagny KM, Finlay BB. Perinatal antibiotic treatment affects murine microbiota, immune responses and allergic asthma. Gut Microbes. 2013;4(2):158-164.

71. Russell SL, Gold MJ, Reynolds LA, et al. Perinatal antibiotic-induced shifts in gut microbiota have differential effects on inflammatory lung diseases. J Allergy Clin Immunol. 2015;135(1):100-109.

72. Arrieta MC, Stiemsma LT, Amenyogbe N, Brown EM, Finlay B. The intestinal microbiome in early life: health and disease. Front Immunol. 2014;5:427.

73. Molodecky NA, Soon IS, Rabi DM, et al. Increasing incidence and prevalence of the inflammatory bowel diseases with time, based on systematic review. Gastroenterol. 2012;142(1):46-54. e42; quiz e30.

74. Sellon RK, Tonkonogy S, Schultz M, et al. Resident enteric bacteria are necessary for development of spontaneous colitis and immune system activation in interleukin-10-deficient mice. Infect Immun. 1998;66(11): 5224-5231.

75. Madsen KL, Doyle JS, Tavernini MM, Jewell LD, Rennie RP, Fedorak RN. Antibiotic therapy attenuates colitis in interleukin 10 genedeficient mice. Gastroenterol. 2000;118(6):1094-1105.

76. Bamias G, Marini M, Moskaluk CA, et al. Down-regulation of intestinal lymphocyte activation and Th1 cytokine production by antibiotic therapy in a murine model of Crohn's disease. J Immunol. 2002;169(9): 5308-5314.

77. Hoentjen F, Harmsen HJ, Braat H, et al. Antibiotics with a selective aerobic or anaerobic spectrum have different therapeutic activities in various regions of the colon in interleukin 10 gene deficient mice. Gut. 2003;52(12):1721-1727.

78. Shaw SY, Blanchard JF, Bernstein CN. Association between the use of antibiotics and new diagnoses of Crohn's disease and ulcerative colitis. Am J Gastroenterol. 2011;106(12):2133-2142.

79. Hviid A, Svanström H, Frisch M. Antibiotic use and inflammatory bowel diseases in childhood. Gut. 2011;60(1):49-54.

80. Shaw SY, Blanchard JF, Bernstein CN. Association between the use of antibiotics in the first year of life and pediatric inflammatory bowel disease. Am J Gastroenterol. 2010;105(12):2687-2692.

81. Koido S, Ohkusa T, Kajiura T, et al. Long-term alteration of intestinal microbiota in patients with ulcerative colitis by antibiotic combination therapy. PLoS One. 2014;9(1):e86702.

82. Rogier EW, Frantz AL, Bruno ME, et al. Secretory antibodies in breast milk promote long-term intestinal homeostasis by regulating the gut microbiota and host gene expression. Proc Natl Acad Sci USA. 2014;111(8):3074-3079.

83. Barclay AR, Russell RK, Wilson ML, Gilmour WH, Satsangi J, Wilson DC. Systematic review: the role of breastfeeding in the development of pediatric inflammatory bowel disease. J Pediatr. 2009;155(3): 421-426.

84. Karvonen M, Viik-Kajander M, Moltchanova E, Libman I, LaPorte R, Tuomilehto J. Incidence of childhood type 1 diabetes worldwide. Diabetes Mondiale (DiaMond) Project Group. Diabetes Care. 2000;23(10): 1516-1526.

85. DIAMOND Project Group. Incidence and trends of childhood Type 1 diabetes worldwide 1990-1999. Diabet Med. 2006;23(8): $857-866$

86. D’Angeli MA, Merzon E, Valbuena LF, Tirschwell D, Paris CA, Mueller BA. Environmental factors associated with childhood-onset type 1 diabetes mellitus: an exploration of the hygiene and overload hypotheses. Arch Pediatr Adolesc Med. 2010;164(8):732-738.

87. Virtanen SM, Takkinen HM, Nwaru BI, et al. Microbial exposure in infancy and subsequent appearance of type 1 diabetes mellitus-associated autoantibodies: a cohort study. JAMA Pediatr. 2014;168(8): 755-763.

88. Brugman S, Visser JTJ, Hillebrands JL, Bos NA, Rozing J. Prolonged exclusive breastfeeding reduces autoimmune diabetes incidence and increases regulatory T-cell frequency in bio-breeding diabetes-prone rats. Diabetes Metab Res Rev. 2009;25(4):380-387.
89. Cardwell CR, Stene LC, Joner G, et al. Caesarean section is associated with an increased risk of childhood-onset type 1 diabetes mellitus: a meta-analysis of observational studies. Diabetologia. 2008;51(5): 726-735.

90. Bonifacio E, Warncke K, Winkler C, Wallner M, Ziegler AG. Cesarean section and interferon-induced helicase gene polymorphisms combine to increase childhood type 1 diabetes risk. Diabetes. 2011;60(12): 3300-3306.

91. Mejía-León ME, Petrosino JF, Ajami NJ, Domínguez-Bello MG, de la Barca AM. Fecal microbiota imbalance in Mexican children with type 1 diabetes. Sci Rep. 2014;4:3814.

92. Valladares R, Sankar D, Li N, et al. Lactobacillus johnsonii N6.2 mitigates the development of type 1 diabetes in BB-DP rats. PLoS One. 2010;5(5):e10507.

93. Wen L, Ley RE, Volchkov PY, et al. Innate immunity and intestinal microbiota in the development of Type 1 diabetes. Nature. 2008; 455(7216):1109-1113.

94. Kriegel MA, Sefik E, Hill JA, Wu HJ, Benoist C, Mathis D. Naturally transmitted segmented filamentous bacteria segregate with diabetes protection in nonobese diabetic mice. Proc Natl Acad Sci USA. 2011; 108(28):11548-11553.

95. Hara N, Alkanani AK, Ir D, et al. Prevention of virus-induced type 1 diabetes with antibiotic therapy. J Immunol. 2012;189(8): 3805-3814.

96. Hviid A, Svanström H. Antibiotic use and type 1 diabetes in childhood. Am J Epidemiol. 2009;169(9):1079-1084.

97. Apiwattanakul N, Thomas PG, Iverson AR, McCullers JA. Chronic helminth infections impair pneumococcal vaccine responses. Vaccine. 2014;32(42):5405-5410.

98. Bobat S, Darby M, Mrdjen D, et al. Natural and vaccine-mediated immunity to Salmonella typhimurium is impaired by the helminth Nippostrongylus brasiliensis. PLoS Negl Trop Dis. 2014; 8(12):e3341.

99. Cooper PJ, Espinel I, Paredes W, Guderian RH, Nutman TB. Impaired tetanus-specific cellular and humoral responses following tetanus vaccination in human onchocerciasis: a possible role for interleukin-10. J Infect Dis. 1998;178(4):1133-1138.

100. Cooper PJ, Chico M, Sandoval C, et al. Human infection with Ascaris lumbricoides is associated with suppression of the interleukin-2 response to recombinant cholera toxin B subunit following vaccination with the live oral cholera vaccine CVD 103-HgR. Infect Immun. 2001;69(3):1574-1580.

101. Sabin EA, Araujo MI, Carvalho EM, Pearce EJ. Impairment of tetanus toxoid-specific Th1-like immune responses in humans infected with Schistosoma mansoni. J Infect Dis. 1996;173(1):269-272.

102. Fleming JO, Weinstock JV. Clinical trials of helminth therapy in autoimmune diseases: rationale and findings. Parasite Immunol. 2015;37(6):277-292.

103. Summers RW, Elliott DE, Urban JF Jr, Thompson R, Weinstock JV. Trichuris suis therapy in Crohn's disease. Gut. 2005;54(1):87-90.

104. Sandborn WJ, Elliott DE, Weinstock J, et al. Randomised clinical trial: the safety and tolerability of Trichuris suis ova in patients with Crohn's disease. Aliment Pharmacol Ther. 2013;38(3):255-263.

105. Croese J, O’Neil J, Masson J, et al. A proof of concept study establishing Necator americanus in Crohn's patients and reservoir donors. Gut. 2006;55(1):136-137.

106. Summers RW, Elliott DE, Qadir K, Urban JF Jr, Thompson R, Weinstock JV. Trichuris suis seems to be safe and possibly effective in the treatment of inflammatory bowel disease. Am J Gastroenterol. 2003;98(9):2034-2041.

107. Feary J, Venn A, Brown A, et al. Safety of hookworm infection in individuals with measurable airway responsiveness: a randomized placebo-controlled feasibility study. Clin Exp Allergy. 2009;39(7): 1060-1068.

108. Summers RW, Elliott DE, Urban JF Jr, Thompson RA, Weinstock JV. Trichuris suis therapy for active ulcerative colitis: a randomized controlled trial. Gastroenterol. 2005;128(4):825-832. 
109. Hewitson JP, Grainger JR, Maizels RM. Helminth immunoregulation: the role of parasite secreted proteins in modulating host immunity. Mol Biochem Parasitol. 2009;167(1):1-11.

110. McSorley HJ, O'Gorman MT, Blair N, Sutherland TE, Filbey KJ, Maizels RM. Suppression of type 2 immunity and allergic airway inflammation by secreted products of the helminth Heligmosomoides polygyrus. Eur J Immunol. 2012;42(10):2667-2682.

111. McSorley HJ, Blair NF, Smith KA, McKenzie AN, Maizels RM. Blockade of IL-33 release and suppression of type 2 innate lymphoid cell responses by helminth secreted products in airway allergy. Mucosal Immunol. 2014;7(5):1068-1078.

112. Ruyssers NE, De Winter BY, De Man JG, et al. Therapeutic potential of helminth soluble proteins in TNBS-induced colitis in mice. Inflamm Bowel Dis. 2009;15(4):491-500.

113. Cançado GG, Fiuza JA, de Paiva NC, et al. Hookworm products ameliorate dextran sodium sulfate-induced colitis in BALB/c mice. Inflamm Bowel Dis. 2011;17(11):2275-2286.

114. Schnoeller C, Rausch S, Pillai S, et al. A helminth immunomodulator reduces allergic and inflammatory responses by induction of IL-10producing macrophages. J Immunol. 2008;180(6):4265-4272.

115. Ferreira I, Smyth D, Gaze S, et al. Hookworm excretory/secretory products induce interleukin-4 (IL-4)+ IL-10+ CD4+ T cell responses and suppress pathology in a mouse model of colitis. Infect Immun. 2013;81(6):2104-2111.

116. Zaccone P, Fehérvári Z, Jones FM, et al. Schistosoma mansoni antigens modulate the activity of the innate immune response and prevent onset of type 1 diabetes. Eur J Immunol. 2003;33(5):1439-1449.

117. Culley FJ, Brown A, Conroy DM, Sabroe I, Pritchard DI, Williams TJ. Eotaxin is specifically cleaved by hookworm metalloproteases preventing its action in vitro and in vivo. J Immunol. 2000;165(11): 6447-6453.

118. Grainger JR, Smith KA, Hewitson JP, et al. Helminth secretions induce de novo $\mathrm{T}$ cell Foxp3 expression and regulatory function through the TGF- $\beta$ pathway. J Exp Med. 2010;207(11):2331-2341.

119. Rausch S, Held J, Fischer A, et al. Small intestinal nematode infection of mice is associated with increased enterobacterial loads alongside the intestinal tract. PLoS One. 2013;8(9):e74026.

120. Reynolds LA, Smith KA, Filbey KJ, et al. Commensal-pathogen interactions in the intestinal tract: lactobacilli promote infection with, and are promoted by, helminth parasites. Gut Microbes. 2014;5(4): 522-532.

121. Walk ST, Blum AM, Ewing SA, Weinstock JV, Young VB. Alteration of the murine gut microbiota during infection with the parasitic helminth Heligmosomoides polygyrus. Inflamm Bowel Dis. 2010;16(11): 1841-1849.

122. Schultz M, Veltkamp C, Dieleman LA, et al. Lactobacillus plantarum $299 \mathrm{~V}$ in the treatment and prevention of spontaneous colitis in interleukin-10-deficient mice. Inflamm Bowel Dis. 2002;8(2): 71-80.

123. Nanda Kumar NS, Balamurugan R, Jayakanthan K, Pulimood A, Pugazhendhi S, Ramakrishna BS. Probiotic administration alters the gut flora and attenuates colitis in mice administered dextran sodium sulfate. J Gastroenterol Hepatol. 2008;23(12):1834-1839.

124. Calcinaro F, Dionisi S, Marinaro M, et al. Oral probiotic administration induces interleukin-10 production and prevents spontaneous autoimmune diabetes in the non-obese diabetic mouse. Diabetologia. 2005;48(8):1565-1575.

125. Duan FF, Liu JH, March JC. Engineered commensal bacteria reprogram intestinal cells into glucose-responsive insulin-secreting cells for the treatment of diabetes. Diabetes. 2015;64(5):1794-1803.
126. Tang ML, Ponsonby AL, Orsini F, et al. Administration of a probiotic with peanut oral immunotherapy: a randomized trial. J Allergy Clin Immunol. 2015;135(3):737-744. e8.

127. Rosenfeldt V, Benfeldt E, Nielsen SD, et al. Effect of probiotic Lactobacillus strains in children with atopic dermatitis. JAllergy Clin Immunol. 2003;111(2):389-395.

128. Oliva S, Di Nardo G, Ferrari F, et al. Randomised clinical trial: the effectiveness of Lactobacillus reuteri ATCC 55730 rectal enema in children with active distal ulcerative colitis. Aliment Pharmacol Ther. 2012;35(3):327-334.

129. Kruis W, Fric P, Pokrotnieks J, et al. Maintaining remission of ulcerative colitis with the probiotic Escherichia coli Nissle 1917 is as effective as with standard mesalazine. Gut. 2004;53(11):1617-1623.

130. Abrahamsson TR, Jakobsson T, Björkstén B, Oldaeus G, Jenmalm MC. No effect of probiotics on respiratory allergies: a seven-year follow-up of a randomized controlled trial in infancy. Pediatr Allergy Immunol. 2013;24(6):556-561.

131. Boyle RJ, Bath-Hextall FJ, Leonardi-Bee J, Murrell DF, Tang ML. Probiotics for the treatment of eczema: a systematic review. Clin Exp Allergy. 2009;39(8):1117-1127.

132. Feighery LM, Smith P, O'Mahony L, Fallon PG, Brayden DJ. Effects of Lactobacillus salivarius 433118 on intestinal inflammation, immunity status and in vitro colon function in two mouse models of inflammatory bowel disease. Dig Dis Sci. 2008;53(9): 2495-2506.

133. Cummings JH, Macfarlane GT, Englyst HN. Prebiotic digestion and fermentation. Am J Clin Nutr. 2001;73(2 Suppl):415S-420S.

134. Vos AP, van Esch BC, Stahl B, et al. Dietary supplementation with specific oligosaccharide mixtures decreases parameters of allergic asthma in mice. Int Immunopharmacol. 2007;7(12):1582-1587.

135. Koleva PT, Valcheva RS, Sun X, Gänzle MG, Dieleman LA. Inulin and fructo-oligosaccharides have divergent effects on colitis and commensal microbiota in HLA-B27 transgenic rats. Br J Nutr. 2012;108(9): 1633-1643.

136. Benjamin JL, Hedin CR, Koutsoumpas A, et al. Randomised, doubleblind, placebo-controlled trial of fructo-oligosaccharides in active Crohn's disease. Gut. 2011;60(7):923-929.

137. de Kivit S, Saeland E, Kraneveld AD, et al. Galectin-9 induced by dietary synbiotics is involved in suppression of allergic symptoms in mice and humans. Allergy. 2012;67(3):343-352.

138. van der Aa LB, Heymans HS, van Aalderen WM, et al; Synbad Study Group. Effect of a new synbiotic mixture on atopic dermatitis in infants: a randomized-controlled trial. Clin Exp Allergy. 2010;40(5): 795-804.

139. van der Aa LB, van Aalderen WM, Heymans HS, et al; Synbad Study Group. Synbiotics prevent asthma-like symptoms in infants with atopic dermatitis. Allergy. 2011;66(2):170-177.

140. Furrie E, Macfarlane S, Kennedy A, et al. Synbiotic therapy (Bifidobacterium longum/Synergy 1) initiates resolution of inflammation in patients with active ulcerative colitis: a randomised controlled pilot trial. Gut. 2005;54(2):242-249.

141. Lue KH, Sun HL, Lu KH, et al. A trial of adding Lactobacillus johnsonii EM1 to levocetirizine for treatment of perennial allergic rhinitis in children aged 7-12 years. Int J Pediatr Otorhinolaryngol. 2012;76(7):994-1001.

142. Xiao JZ, Kondo S, Yanagisawa N, et al. Clinical efficacy of probiotic Bifidobacterium longum for the treatment of symptoms of Japanese cedar pollen allergy in subjects evaluated in an environmental exposure unit. Allergol Int. 2007;56(1):67-75. 
ImmunoTargets and Therapy

\section{Publish your work in this journal}

ImmunoTargets and Therapy is an international, peer-reviewed open access journal focusing on the immunological basis of diseases, potential targets for immune

based therapy and treatment protocols employed to improve patient management.

Basic immunology and physiology of the immune system in health, and disease will be also covered. In addition, the journal will focus on the impact of manage-
Dovepress

ment programs and new therapeutic agents and protocols on patient perspectives such as quality of life, adherence and satisfaction. The manuscript management system is completely online and includes a very quick and fair peer-review system, which is all easy to use. Visit http://www.dovepress.com/testimonials.php to read real quotes from published authors.

Submit your manuscript here: http://www.dovepress.com/immunotargets-and-therapy-journal 